\title{
Islamism and Social Reform in Kerala, South India
}

\section{FILIPPO OSELLA* and CAROLINE OSELLA $\dagger$}

\author{
*Department of Anthropology, University of Sussex, Brighton, \\ BNI 9SJ, United Kingdom \\ E-mail: F.Osella@sussex.ac.uk \\ $\dagger$ Department of Anthropology and Sociology, School of Oriental and African \\ Studies, Thornhaugh Street, Russell Square, London, \\ WCIH OXG, United Kingdom \\ E-mail:CO6@soas.ac.uk
}

\begin{abstract}
This paper critiques ethnographic tendencies to idealise and celebrate sufi 'traditionalism' as authentically South Asian. We perceive strong academic trends of frank distaste for reformism, which is then inaccurately-and dangerously buttressing Hindutva rhetoric-branded as going against the grain of South Asian society. This often goes along with (inaccurate) branding of all reformism as 'foreign inspired' or wah'habi. Kerala's Mujahids (Kerala Naduvathul Mujahideen $[\mathrm{KNM}]$ ) are clearly part of universalistic trends and shared Islamic impulses towards purification. We acknowledge the importance to KNM of longstanding links to the Arab world, contemporary links to the Gulf, wider currents of Islamic reform (both global and Indian), while also showing how reformism has been producing itself locally since the mid-19th century. Reformist enthusiasm is part of Kerala-wide patterns discernable across all religious communities: 1920 and 193 os agitations for a break from the $19^{\text {th }}$ century past; 195 os post-independence social activism; post 198 os religious revivalism. Kerala's Muslims (like Kerala Hindus and Christians) associate religious reformism with: a self-consciously 'modern' outlook; the promotion of education; rallying of support from the middle classes. There is a concomitant contemporary association of orthoprax traditionalism with 'backward', superstitious and un-modern practices, troped as being located in rural and low-status locations.
\end{abstract}

\section{Introduction}

In Kerala ${ }^{1}$ we find strong currents of Islamic reformism, the largest organisation being the Kerala Naduvathul Mujahideen (KNM). This

${ }^{1}$ Located on the south-west coast of India, Kerala has a population of 32 millions, split between various Hindu (54\%), Christian (19\%) and Muslim (25\%) communities. 
radical reform movement, originating in the 1920 s and (to date) limited to Kerala state, draws its inspiration from a wide range of strands both within India and from the wider Islamic world. Kerala's Islamic reformism is simultaneously local-in that it emerges within a specific social, political and historical context-and also pan-Islamic or transnational-in that it embodies orientations which historically characterise the development of Islam across the world. While Kerala's Mujahids (as KNM supporters are known) participate in wider currents and are part of a universalistic trend, at the same time, Mujahid projects cannot in any way be tritely subsumed under labels such as 'global Islam' (e.g. Roy 2004). Kerala reformism must be understood as being simultaneously part of a global Islamic impulse towards purification and also as a deeply locally rooted and specific phenomenon, which produces itself on the ground through practice and through dialogue with significant others, Muslim and non-Muslim alike. Indeed, public debate in Kerala between 'reformist' and 'traditionalist' Muslims produces shifts in practice and works continually to generate and redefine the focus of 'reform' and 'anti-reform'.

We are here critiquing anthropological tendencies to idealise and celebrate sufi 'traditionalism' as somehow authentically South Asian in contrast to reformism, which is then inaccurately-and dangerously buttressing Hindutva rhetoric-branded as going against the grain of South Asian society. We are also highlighting a related issue: what we perceive as an anthropological bias, taking the form of a fondness for sufism and a distaste for reformism-a stance which often goes along with the careless branding of reformism per se as 'wah'habi' or 'foreign inspired'. Looking at Nile Green's work on sufi reformism in Hyderabad (2005), or groups like the Farangi Mahall (Robinson 2001b) and the Barelwis (Sanyal 1996), but also Deoband and Tablighi Jama'at (Sikand 2007) reminds us that since the 19th century, South Asian Islam at large has been moulded by various strands of reformism, and that actually sufism and reformism are not polarised categories to be pitted against each other (although they normally appear to be so from ulema and activist rhetorics).

If historians have sometimes over-asserted the theological dimensions of South Asian reformism, and framed discussion within

\footnotetext{
${ }^{2}$ Research was funded by the ESRC, Nuffield foundation, the AHRC and SOAS; see ESRC REGARD website for a summary of the project. Thanks for comments on early drafts to: Irfan Ahmad; Patricia and Roger Jeffery; Edward Simpson; Ben Soares; Atreyee Sen; Shajahan Madampat.
} 
an Islamic 'great tradition' rooted in a putatively shared core, anthropologists have (over) reacted against this tendency and at the same time given rein to their (aesthetic, political, emotional) preferences for sufi-inspired Islam. Indian anthropologist Imtiaz Ahmad's position is clear when he asserts, "Most puritanical and orthodox Muslims see any form of sufism or close interchange with other religions as a danger to true Islam" (Ahmad \& Reifeld 2004: p. xxii), before he moves on to celebrate a putatively 'Indian Islam'. We need to interrogate this sort of stance and terminology: Ahmad's distaste for reformism is clear-but is it fair? We want to redress the balance by appreciating the very local (and unassailably 'authentic') specificity of Kerala's highly radical reform movement and by placing the KNM agenda into its context as part of wider Malayali concerns with social reform and 'progress'. We worked for several years among low caste Hindus and have written about their reform movements (e.g. Osella \& Osella 2000). What strikes us often in talking to Mujahid supporters is a familiarity of discourse. Studying Islamic reform only in the context of material on Islam (whether Orientalist or ethnographic) makes for a lopsided picture. As Nile Green argues (this volume), the broader social landscape is deeply relevant. While we see longstanding Arab links, contemporary Gulf links, India-wide currents of Islamic reform and so on in Kerala's KNM, we must also take careful account of its local roots. Here then, we situate this material as part of Kerala's highly particularistic history of socio-economic transformations.

Historians have traced the emergence of reformist trends in late 18th-century South Asia to specific circumstances: the decline of Muslim political power, the growing influence of British colonialism and, later, the emergence of Hindu revivalism (Robinson 2001b: 184ff; cf. Metcalf 1982; Sanyal 1996; Mayaram 1997; Robinson 2001a, 2004; Sikand 2002). While a reformist tradition is perhaps as old as Islam itself, reformism appears in this literature as an engagement with the 'modern': a universalistic and rationalising orientation-often compared to the Christian reformationarticulated in a complex dialogue with (at times in opposition to) colonial and postcolonial 'western' modernities (Robinson this volume; cf. Eickelman \& Piscatori 1996; Salvatore 1997; Kahn n.d.). While such readings place Islamic reformism squarely within modernity, an overemphasis on theological debates and the religious milieu (see e.g. Mahmood 2004; Deeb 2006; Hirschkind 2006) has produced a reexoticisation effect, which sets reformism as a uniquely 'Muslim' way to be modern. 
From a Kerala perspective, Islamic reformism is not at all peculiar. The reformist programmes articulated from the end of the 19th century onwards by various Hindu and Christian communities have much in common with similar processes taking place amongst Kerala Muslims; all are responding to and reflecting upon similar historical contingencies and also reacting to each other-a point made by historians with reference to the emergence of (middle class) reformism in North India (e.g. Robinson 1993a,b; Joshi 2001; Gupta 2002; Walsh 2004; Green this volume), but somewhat lost in recent research. Kerala reformists are concerned to shape behaviour with reference both to reformism elsewhere and also to Kerala communities. Refuting any sort of Muslim or Islamic exceptionalism, we argue that if on the one hand Islamic reformism, in Kerala as elsewhere, has a clear universalistic orientation, seeking to disembed religious practices from cultural specificities, on the other it remains inflected by-or embedded in - the historically specific social and political contexts of its emergence, which eventually define orientations and debates. In other words, not only are categories such as 'reformed' and 'traditionalist' Islam unstable and produced discursively-to the extent that their content undergoes huge shifts-but, moreover, we cannot assume either the direction or the orientation which reformist discourse and practice will take in specific locations.

\section{Kerala's Muslims}

All Kerala Muslims are Sunnis of the Shafi school. But since the rise of reformism, these days the term 'Sunni' is used to mean 'orthodox' or 'traditionalist' Muslims: those who stand opposed to the organised reformists. While Kerala does have a few adherents to the TablighiJama'at, and some followers of Jama'at-i-Islami, by far the two biggest groupings of Muslims, and the most culturally salient distinction, is that between 'Sunnis' and 'Mujahids' (Miller 1976: 275ff; Abdul Haque 1982; Samad 1998; Sikand 2005: 13off). Both groups run and have control of mosques, madrasas, schools, colleges and orphanages, and both are formally split into two rival factions. Contemporary Mujahids are divided between an 'official' group from the original organisation, headed by T. P. Abdulla Koya Madani; and a largely Kozhikode ${ }^{3}$-based splinter Mujahid grouping led by the

\footnotetext{
${ }^{3}$ Formerly known by its colonial name of Calicut, with a population of roughly 400,000 people, Kozhikode is Kerala's third largest city and, although Muslims are
} 
former youth/student leader Hussain Madavoor. Sunnis are equally split between two factions-one led by E.K. Aboobaker Musaliar and one by Kanthapuram A.P. Aboobaker Musaliar. An early ulema reformist group-the Aikya Sangam-was founded in 1922 and is generally recognised to be the precursor of today's KNM (and the wider Mujahid) movement, described by Sikand as, "the Kerala counterpart of the Ahl-i-Hadith in north India" (2005: 131). ${ }^{4}$ While Mujahids themselves admit to having only $10 \%$ of Kerala's Muslim population affiliated as followers, they claim far wider influence; the reformist and modernising impulses promulgated by Mujahids have, since the 1920 , set the agenda for the direction of the community in general.

A point we must stress immediately is that Kerala Muslims are quite distinct from north Indian Muslims and even from many Tamil groups (Mines 1973, 1975; Bayly 1992: 7 1ff; McGilvray 1989, 1998; Fanselow 1996). Islam in Kerala spread early, through Arab trade and, later, travelling Hadrami saints; and Kerala's Muslims have an unbroken, longstanding and deep direct connection with the Gulf region. Muslims in Kerala are not Urdu speakers and (around coastal Malabar especially), Arabic is deeply entrenched. Sikand (2005: 126) estimates 6,ooo Arabic teachers and 500,000 students across Kerala. Schools offer prizes and run competitions for Arabic poetry, composition, song and so on; Kerala Muslim folk arts (such as the daf) are heavily Arabicised. Until the 1960s, Arabi-Malayalam (Malayalam language written into Arabic script) was in wide use-it is still taught in Sunni Arabic colleges ${ }^{5}$ and is still used by some nowadays. In sum, there is generally a strong Arabic thread running through Kerala Muslim culture, especially marked in Malabar and reinforced by extensive post-1970s migration to the Gulf (Osella \& Osella 2007a). We underline this, because it is most important to remember the historical and cultural depth of coastal Kerala's ties to the Arab world when engaging with various popular (negative) characterisations of

not the majority, it is considered to be the Muslim capital of Kerala. Kozhikode Town, at the centre of Kozhikode district, sits right next to the Muslim-majority district of Malappuram.

${ }^{4}$ While there are many ideological differences between KNM and Ahl-i-Hadith, the two organisations have strong ties at national level. We thank Shajahan Madampat for drawing our attention to these linkages.

5 'Madrasa' in Malayalam refers to classes where children receive basic Arabic language and religious instruction; Kerala's 'Arabic Colleges' are the equivalent of north Indian madrasas. 
reformism as: 'wah'habism'6; a phenomenon born out of post $1970 \mathrm{~s}$ Gulf migration; inauthentic because of its Arab links. It is equally important to ensure that such mis-identifications do not become part of the academic record and feed blunt generalisations. In refuting sloppy stereotypes, we are drawing on material from three sites: several visits into the rural Muslim-majority district of Malappuram, adjacent to Kozhikode; short field-trips to various locations in the Gulf Cooperation Council (GCG) states; and Kozhikode town, where we and our two children lived from September 2002 to June 2004, on the edge of the Muslim neighbourhood of Thekkepuram, near Kozhikode's big bazaar-until recent waves of globalisation a regional centre for trading in timber, rice, spices, copra and so on.

One of Kerala's most prominent Muslim communities which has been deeply involved in spreading reformism, are Koyas-a group which flourished with colonial and Arab trade until the 1970s and lives in and around Kozhikode's Thekkepuram neighbourhood (Osella \& Osella 2007a). Because of a serious decline in wealth, nowadays Koyas do not correspond to an urban elite but rather to the class fractions of lower middle to middle. While Gellner (1981) argues for locating reformism among urban elites, we note that Koyas correspond sociologically to groups which we commonly find (across all religious communities) as especially likely to be associated with public activism-be it in political parties, social service or even film-star fan clubs (cf. Srinivas 1996; Eickelman and Salvatore 2004: 13 ff; Huq this volume).

\section{The Rise of Reform}

In the Islamic month of Rajab, Thekkepuram's Sheikh Palli (mosque) celebrates its annual five day nercha (urs, shrine festival), at which cloth, oil and body-part shaped appams (rice cakes) are the main items presented at the jaram (dargh, tomb) of Sheikh Mammukoya. Early evening sees crowds throng in, but these are mostly outsiders to Kozhikode-Mappilas from rural Malappuram district-as are those devotees who, late at night before the tomb, perform katti rateeba men's devotional practice involving self-cutting. Local men and women alike condemned the nercha to us as a prime example of shirk

\footnotetext{
${ }^{6}$ As in other parts of the world, and as in colonial usage, 'wah'habi' is often used locally as a highly prejudicial term of abuse (cf. Hermansen 2000).
} 
or attributing partners to God (specifically, 'saint worship') and as something undertaken by the unreformed, the lower class or by the rural ignorant. We could not find people from Thekkepuram willing to accompany either of us inside the mosque while the nercha was going on, even if it was clearly understood that this would be simply for our research. Both of us found people reluctant even to speak about the nercha; most claimed ignorance of what it entailed. Lateef told Filippo, "I can't be seen at the nercha. People will talk and say that I am a Sunni. I don't really care-I am just a Muslim, I don't follow anyone. But you know what our people are like ...”. When some women in a lower status family talked to Caroline, they told her, "The nercha is very interesting. They have an appam for every ill, every size and shape, like kalappam for leg trouble and so on. But we can't see the rateeb... we can't go to the nerch a anyway, because we would get beaten!" To Caroline's wider questioning, women were emphatic that nercha is nothing at all like a Hindu temple festival, and seemed offended even by her question about whether it was any way at all similar-would there be a procession, a flag, would anything be offered at or given out from the shrine and so on. Nercha here is clearly located as part of unreformed 'Sunni' Muslim traditions. But we note that pressure not to attend the nercha is not purely an index of active reformist affiliation; among Kozhikode's Muslim 'respectable' middle classes even those who do not describe themselves as Mujahid supporters feel constrained to stay away.

The conversations we took part in at the fringes of the Sheikh Palli nercha-condemnatory, disavowing, feigning of ignorance and so onare perhaps unremarkable, a rhetoric commonplace across the Islamic world wherever debates between 'traditionalist' and 'reformist' Muslims have been taking place. They are part of wider discussions occurring in the public sphere-in mosques, madrasas, media, public meetings. Such debates actively construct and continually (re)define the content and nature of these two categories (see Asad 1986; Bowen 1993; Soares 2005: 7ff). While some report a youthful educated middle class taking up reformism in critique of a decadent older generation (see e.g. Brenner 1996; Abaza 2002 on Egypt and Malaysia; Abdel Rahman 2006 on Egypt; Jones 2007 on Java; Huq this volume), Kerala reformism follows another of the commonly recognised patterns: an urban, educated middle class waving the stick of reformism at rural, lower class Muslims who stand accused of straying from the path of 'true Islam' (Troll 1978; Metcalf 1982; Robinson 1993a,b, 2001a, 2004; Mayaram 1997; Verkaaik 2001, 2004; Sikand 2002). 
Around Kozhikode, we find that underneath a public discourse on 'Muslim brotherhood'-commonly appealed to in religious meetings to establish participation in a global community, to call for unity among Kerala Muslims and to distance the community from the social practices of non-Muslims-lies a barely disguised hierarchy of statuses. While Malayali Muslims do not talk (as in north India) about the ashraf and ajlaf or use terms like sharif, still they make several grades of local distinction between status groups. Where once Kerala Muslims recognised only status distinctions between themselves based upon ideas about descent and blood or occupational status and class, ${ }^{7}$ sectarian divisions have also grown up between supporters of Islamic reform-'Mujahids' - and those who continue practices deemed by reformism as un-Islamic such as saint and shrine veneration-the 'Sunnis'. The winning over of Thekkepuram's high-status middleclass Koyas to the Mujahid path has left 'Sunni' as inflected with notions of low status and uncouthness. While the Sheikh Palli nercha was once a grand affair, it is now a small event, boycotted by the Koya businessmen who once were its main participants and sponsors. Those who now attend are said to be ignorant rural outsiders or low-status labourers-in Mujahid (and Koya) discourse 'typical Sunnis'. It is unsurprising to find that reformism for this once-grand urban trading group has also become a vehicle for expressing and maintaining class and status distinctions, in the face of widespread economic changes brought by Gulf migration and the decline of Koya-dominated sites of capital accumulation-commerce with Gulf Arabs, which made so many Koya families wealthy, has all but stopped; the timber trade is in terminal decline; the copra and rice trades are progressively moving out of Kozhikode's big Bazaar.

But limiting analysis of this declining urban middle-class Muslim community's withdrawal from nerchas to the politics of status would fail to articulate Koyas' complex relationship to reformism. Steering away from an all too obvious instrumentalism (see Metcalf 1976; Robinson 1993a, 1993b: XIVff, 2001b), we suggest that participation in Mujahid reformist projects of self-making holds a broader significance as index-via notions of education and progress—of a particular

\footnotetext{
${ }^{7}$ An alleged Arab-cum-upper caste origin, together with a long-term association to trade and business, for example, are used by Koyas-Kozhikode's 'dominant', in Srinivas' terms (1966), community-to draw distinction with other lower status Muslims (Osella \& Osella 2007a; cf. Mines 1973, 1975; Fanselow 1996; McGilvray 1989, 1998; Bayly 1989: 7 1ff; Vatuk 1996; Simpson 2006: 87ff.).
} 
mode of engagement with the modern, ${ }^{8}$ leading to interrogations of orthopraxy and arousing anxiety over association with practices deemed 'backward' and un-modern.

\section{Kerala's Mujahid Reformism}

We meet the amiable and energetically busy Dr. Hussein Madavoor in his neat office at Ithihadu Shubbanil Mujahideen (ISM-youth wing of the KNM). Madavoor studied for five years in Saudi Arabia and has recently finished a PhD at Calicut University. An Arabic and Islamic scholar, he is director of the Rouzathul Uloom Arabic College (part of Faroke College, Kerala's first Muslim university). Madavoor started his career in ISM, from which he split to become leader of the KNM-Madavoor group. Madavoor tells us that, "The Mujahid movement is about religion, education, science and progress" and goes through some major points of difference: Mujahids avoid prayer at saints' tombs and accuse Sunnis who do this of shirk; Mujahids oppose celebrations such as prophet's birthday; Mujahids worked for translation of Quran into vernacular, Friday sermons in vernacular and more generally for education and understanding; Sunnis use Arabic in their mosques; while Sunnis ban women from mosques, Mujahids encourage female attendance; Sunnis follow the 4 oo year old shafi text, Fathul Mu-een, by Sheikh Zainudhin Makhdum II; Mujahids believe $f q$ to be irrelevant. Madavoor explained,

"Fathul Mu-een is an important text, used in many Egyptian and Saudi universities. But Sunnis take shafi fatwas as given, while we say that Muslims should find solutions to current problems from Quran and Sunnah, considering later interpretations only as opinions, possible solutions ... Most important is the Quran, Sunnah and interpretations of first generation of Muslims...We are called reformists, but it is the opposite: We want to return to the true Islam of the Quran".

Madavoor's summary of the Mujahid movement aligned it with mainstream Islamic reformism: condemnation of shirk (attribution of partners to God; idolatry), of bidah (innovations in worship) and of taqlid (blind following), with a stress on the importance of ijtihad (reasoned interpretation).

\footnotetext{
${ }^{8}$ While the 'modern' used to be simply associated to the practices of the colonisers, in post-independence times 'modernity' becomes highly nuanced through Kerala, Gulf and Western modernities (Osella \& Osella 2007a; c.f. Deeb 2006).
} 
A member of the KNM (official faction) spoke to us:

Islam has been polluted by false knowledge. People are kept in ignorance and superstition so that priests [Sunni clergy] can fill their bellies and keep control, justifying their existence. You can read in Logan's book [Malabar Manual] about the pitiful condition of Muslims in 1 $9^{\text {th century Kerala. People }}$ were not allowed even to learn Malayalam script-it was considered haram. Ignorance leads to superstition and other un-Islamic practices. When in crisis, people call the name of Sheikh Moihudeen. ${ }^{9}$ You may have heard of the Moihudeen mala in his honour. ${ }^{10}$ Women especially read the mala, and they believe they will get merit from doing so. He might have been a great man, but this is shirk. Praying to saints, prostrating in front of their jarams [tombs] is forbidden. The Prophet himself did not want to have a grave! People go to shrines asking saints for help or miracles, but only God can help.

Education-understood at KNM headquarters as direct access to religious knowledge-is then presented as essential for the Kerala Muslim masses of whom, according to Mujahid ulema, "9o\% commit shirk without knowing it". Mujahids are committed to fighting on all fronts for ijtihad (reasoned argument) and to combat the ignorance which, they argue, leads to the triple faults of shirk (deviation from monotheism), bidah (innovations in worship) and taqlid (blind following). A defining trope in Mujahid historical narratives and current rhetoric is the struggle for education in the face of traditionalist opposition.

Mujahid ulema were organised from the 1920 s, but in the $195^{\text {os }}$ they decided to form a mass organisation, the KNM ... there was plenty of opposition from Sunnis. Stones were thrown at them, because they threatened the power of the Sunni clergy. Sunni ulema opposed translation of the Quran into Malayalam because they knew that once people could read the Quran by themselves they would understand true Islam and abandon them. But the Quran was translated...Again, in 1986 the Mujahid conference declared that dowry was un-Islamic. Sunnis immediately replied that dowry was allowed, but a few years later they also began to say it is un-Islamic ... Every time they are challenged, they backtrack-because we present evidence from the Quran. People nowadays can read the Quran and they know we are right. People are becoming more literate and sophisticated, but still in the rural areas there is no light of learning, sometimes there are still physical attacks against us.

This stress on understanding and rational thought extends for Mujahids to education more widely conceived. Reform through the

\footnotetext{
${ }^{9}$ Al-Jilani, $1078-1167$, founder of the Qadiris sufi sect; see Miller 1976: 242; McGilvray 2004.

${ }^{10}$ A famous ballad-Miller 1976: 288-289; cf. Schomburg 2003.
} 
advancement of religious as well as secular education has been a central plank of the Mujahid reformist project since the 1920s: formal madrasas were set up, curricula were standardized, teachers were trained and eventually Arabic colleges were started (see Miller 1992: 2004ff; Pasha 1995; Sikand 2005: $122 \mathrm{ff}$; cf. Metcalf 1982). Reformist leaders such as Vakkom Moulavi and Makti Thangal campaigned in the erstwhile princely states of Travancore and Cochin respectively for the introduction of schools where Islamic subjects would be taught alongside 'modern' disciplines. In Malabar, CN Ahmed Moulavi-the reformist leader who first translated the Quran into Malayalam and worked from 1931 to 1949 as a religious instructor in a Government Muslim High School-started a college under the auspices of the Ernad Educational Association (Miller 1992: 209-2 10). When in 1934 the Aikya Sangham-the predecessor of the KNM—-was disbanded, it donated its existing funds towards the foundation of Kerala's first Muslim college at Faroke (Miller 1992: 207). And the orthodox Sunni establishment eventually responded to Mujahid enthusiasm in kind. Confrontations between Sunni and Mujahid over the hearts and souls of Kerala Muslims takes place these days not only through control of mosques but, crucially, through the number of educational institutions run (cf. Zamam 1999; Alam this volume).

The Samasta Kerala Jam'iyyatul Ulama, the main Sunni organisation, started in the late 1920 s as a response to the growing influence of Wakkom Moulavi's Aikya Sangamam. ${ }^{11}$ In interviews, its leaders were just as eager to show us their commitment to education: they claim control over more than 8,ooo madrasas (against some $5^{\mathrm{OO}}$ Mujahid madrasas) with one million students and 72,00o registered teachers, as well as a string of Arabic colleges and, more recently, even an engineering college. Even the staunchly anti-reformist Jamia Markazu Ssaqafathi Ssunniyya (led by Kanthapuram A.P. Aboobaker Musaliar)—which in the past concentrated on male-only religious education-nowadays runs Malayalam and English medium arts, science and technology colleges for both boys and girls.

The Samasta has also moved away from its early complete condemnation and boycott of reformist ulema, arguing instead that their ideas are "too complex for common people, creating confusion

${ }^{11}$ In the same way as in north India Barelwis emerged in reaction to the growing influence of Deoband (Metcalf 1982: 295). 
and leading Muslims away from Islam". ${ }^{12}$ At the same time, it works to refute accusations of 'traditionalism' by reminding Muslims that past Sunni leaders not only took a leading role against British colonialism but also worked towards the spread of 'correct' Islamic practices. The renowned Mamburam Thangal (Sayyid Fazl Pookoya Thangal) wrote, for example, famous fatwas in the late $19^{\text {th century against the }}$ British as well as stinging attacks against Shi'a sufi practices. He also exhorted Mappilas to follow "proper Muslim ways", such as covering the breasts of women, not working on Friday and refusing to accept left over food from Hindu landlords. Certainly, it is easy to forget nowadays the degree to which the bugbear of Mujahids, Thangals (Sayyids claiming descent from the Prophet and generally associated to Sunni traditionalism) ${ }^{13}$ have acted as reformists (Sathar 1999; Mobini-Kesheh 1997; cf. Sanyal 1996; Green 2005).

But to reformists, Sunnis' understanding of and recent promotion of education is far too limited, and their continued stress on Arabic colleges reveals their 'backward' orientation. "What is the point of spending so many years studying Islamic jurisprudence?" asked one Mujahid activist friend: "You only need to know the Quran and Sunnah. And what is the need for so many religious scholars? What job can you get after that? Students go to Sunni Arabic colleges because they get full scholarships. Their families are poor and illiterate and think that this is proper education. This is also why Sunnis do not want people to learn [the Quran]: then people have to rely on moulavis ... they pay moulavis to pray and recite the Quran. So Sunnis make a good living out of people's ignorance".

Filippo meets another activist, MM Akbar-science graduate, prolific writer of reformist religious books and moving force behind 'The niche of truth', a KNM-sponsored group-after he delivered a speech at the final public meeting of the 'Timekkedinnu,

12 To get a sense of the tone of public debates between Sunni and Mujahid ulema in the 1970s see Ernadan's (1979) summary of the 'Kuttichira Debate'.

${ }_{13}$ Thangals, standing apart for their undisputed Yemeni origin (Hadrami Sayyids), claim higher status, as a Sayyid community whose families hold written genealogies linking them back to the Prophet (Dale 1997; Sathar 1999; Laffan 2002; Freitag 2003; Ho 2006). While Mujahids criticise Thangals for using their ritual status to "promote superstition" and to accumulate wealth, Thangals remain respected as religious and political leaders amongst Muslims of the interior-Malappuram district's Mappilas-a group which is patrilineal and (until 1970s Gulf migration) largely agricultural, poor and, according to Kerala standards, uneducated (Miller 1992; Dale 1980; Panikkar 1989). 
Nanmayilleku (away from vice, towards virtue) campaign. ${ }^{14}$ Sitting in the back seat of a jeep, Akbar tells Filippo,

Muslims still lag behind in education, because in the past the clergy did not want anyone to learn either Malayalam or English—only Arabic. Malayalis are different from North Indian Muslims: we speak like Malayalis, dress like Malayalis, we have the same Malayali local culture. In north India you can spot Muslims, Hindus or Christians by their dress culture. Even in Tamil Nadu and Hyderabad you can see Urdu separateness. But here we are totally Malayali. Muslims used Arabic Malayalam in the past because they were not literate in Malayalam, but now we all know how to write in Malayalam script. What is more, people have been in the Gulf and realised that education is needed. Because of the Gulf, Muslims are now happy and have self-respect, self-reliance and confidence. In north India, Muslims are still illiterate, poor and keep caste differences. In Kerala, only the Thangals keep caste-we ignore it. Kerala is generally progressive, educated and modern, so Islamist movements here are progressive. If Muslims don't know English, how can they communicate and learn? The West and USA put around wrong information and rumours about Islam, they twist facts. How can Muslims counteract this without knowing English? How can I become a doctor or engineer without modern education? I will remain forever downtrodden. The main truth of Mujahid is the spread of education.

Activist rhetoric reveals some of the contradictions or tension within Mujahid discourse. While Mujahids proudly declare that, "Nowadays there are many Muslim women who are teachers, doctors and government employees" and while a picture of young pardah wearing girls learning to use computers invariably appears in Mujahid publications, at the same time they stress that women's employment should not be actively encouraged. Rather, "educated women"-by which Mujahids generally intend women with high school matriculation plus basic religious (madrasa) qualifications-are envisaged as the prop for the family as a whole, fostering religious morality and promoting the education of the children (cf. Jeffery et al. 2004; Minault 1998; Metcalf 2002).

The role attributed to women becomes particularly significant in the context of Mujahids' increasingly wide-reaching attempts to rid Kerala Islam of what they consider to be un-Islamic practices. While it is recognised that some degree of adaptation to 'local culture' is unavoidable, there is a growing realisation that much of Kerala's 'secular' public culture and spaces are in fact Hindu-oriented and should be resisted as part of the work of purification (see discussion of,

14 11.1.04. The Bahrain Parliament Speaker, Ashaiq Aadil Abdurrahiman Almuaavidha, inaugurated the final public meeting on Kozhikode beach. 
in the Jefferys' phrase, 'banal Hinduism' in Osella \& Osella 2007b: 9). It is women who are expected to shift family practice so that children will grow knowing 'true' Islamic culture and will have a habitus formed in an Islamic manner (Jeffery et al. 2004; cf. Hirschkind 2001, 2006; Mahmood 2004). In practice, women make careful and finely nuanced compromises. Caroline and her children were invited to a birthday tea for a five year old Muslim girl, where the womenfolk had bought a birthday cake-an item which they told Caroline was actually haram and certainly prohibited by their family's (Mujahid) menfolk (who were out of the house). When Caroline and her children began to sing the 'Happy Birthday to you' song, nobody joined in. Women explained that they had recently given up singing the birthday song; they really should not be buying cake or celebrating at all. But, they reasoned, you cannot be so mean to a small child as to deny them the 'birthday party' that their classmates enjoy. Cake, but no singing, in the menfolk's absence (and presumed or feigned ignorance) was a reasoned and negotiated compromise.

In 2003, heated debates in Malayalam Muslim daily newspapers followed the inauguration of a public function by a Muslim League minister who began the proceedings by lighting a vilakku (oil lamp). While this is standard practice on such occasions, lamp lighting is of course derived from Hindu religious rituals, which leads reformist groups to brand it as un-Islamic and to demand that Muslim politicians refrain from the practice. Reformists have also recently advised Muslims against celebrating Onam [Malayali Hindu new year] or Christmas with non-Muslim neighbours. This turn has undoubtedly been reinforced by national and international political events, widely interpreted throughout the community as evidence of an attack on Islam and arousing among Muslims a sense of being a 'community under siege' which needs to stick together. ${ }^{15}$ It also follows a generational shift: there is intensified attention to what is 'un-Islamic' in the ideological orientation of the Mujahid movement.

\section{Mujahid Roots and Influences}

Mujahids generally claim religious affinity with the full gamut of Islamic reformism—from Ibn Taimiyah (1 262-1327), Sheikh Ahmad

\footnotetext{
${ }^{15}$ Economic liberalisation, intensifying bourgeoisification and Kerala's powerful consumer culture, resulting in increasing privatisation of education and healthcare, is also playing into schismatic processes (cf. Jeffrey et al. 2004).
} 
Sirhindi (1563-1624), Shah Waliyullah (1702-1763), Mohammad ibn Abdul Wah'hab (1703-1792) and Sayyid Ahmad Khan (1817$1898)$ to Jamaluddin al-Afghani (1839-1897), Muhammud Abduh (1849-1905) and Rashid Rida (1856-1935). The fact that in contemporary discourse it is often Abdul Wah'hab's name which is popularly cited as foundational influence is not as obvious as it might seem. Kerala reformism has complex historical roots.

The ideals of reformism and pan-Islamism are likely to have circulated amongst Kerala's Ulema at least from the mid-19th century, brought from Hijaz by Hajj pilgrims (see Laffan 2002) and by the (Thangal) Hadrami Sayyids' diaspora which reached Kerala in the early 18th century (see Dale 1997; Freitag \& Clarence-Smith 1997; Laffan 2002; Freitag 2003; Ho 2006). Reformists, emerging in the wake of the 1921 Mappila lahala, also had significant contacts with north Indian pan-Islamism through connections established within the Khilafat movement (Dale 1980; Panikkar 1989: $122 \mathrm{ff}$; Miller 1992: $128 f f$.; Rawther 1993; cf. Minault 1982). In the late 19th century and early 2oth century, reform drew as much from Vellore's Arabic colleges (Tamil Nadu) - where early reformists such as Chalilakattu Kunjahmad Haji (d. 1919) and Hamadani Thangal (d. 1922) were found - as it did from the Egyptian reformism of Abduh as propagated through the pages of Al-Manar (Haddad 2006) - a journal to which many founding fathers of the Mujahid movement subscribed (Miller 1976: 265ff; Abdul Haque 1982; Samad 1998). ${ }^{16}$

But in contemporary Mujahid narratives, the name of Abdul Wah'hab obscures the heterogeneous roots of the movement, as ulema prefer to establish historical continuity with Saudi Arabian and Gulf States connections-Kuwait and Bahrain in particular. It is here that many Mujahid scholars train nowadays-many contemporary ulema hold post-graduate degrees from Saudi Islamic Universities. Arab ulema are regularly invited to address public religious meetings and local doctrinal conflicts are sent to Saudi religious scholars for adjudication. Saudi, Kuwaiti and Bahraini religious organisations provide financial support and ideological legitimation to the movement. While a pan-Islamic orientation is not new-consider the circulation of religious scholars and reformist ideas between mid-18th and early 2oth century-it has been

${ }^{16}$ Al-Manar reached well beyond Kerala's reformist circles. Kozhikode's Valiya Qazi-a moderate Sunni Thangal-told us that his father (the former Qazi and by no means a reformist) had studied in Cairo and, like many others in Kerala, had held a postal subscription to Al-Manar. 
significantly strengthened over the last 30 years. Not only has Gulf migration brought thousands of Malayali Muslims close to what they imagine as the heartland of Islam and exposed them-with all ensuing contradictions and ambivalences-to life in Muslim-majority countries, but it has also renewed ties with Arab religious scholars. There is a sense of participating in a worldwide renaissance of Islamic "moral values and culture". An Islamic renaissance, Mujahids argue, would not just rid Kerala of the social problems-decline of family, consumerism, pornography-brought to bear on Muslim lives by globalisation (the negative side of Gulf migration) but would also set the basis for counteracting 'western imperialism'. These are understood to be problems faced by Muslims worldwide that can only be addressed by a unified Muslim community. ${ }^{17}$

Yet Mujahids-especially the KNM-Madavoor faction-are also keenly aware of the differences between themselves and the most radical forms of 'Wa'habi' reformism in the Gulf. ${ }^{18}$ This is so, for example, with regard to prescriptions on male self-presentation, on women's access to mosques and a preference for using Arabic in sermons: these are all orientations which Mujahids feel to be inauthentic and unreformed-indeed, they are associated to traditionalist Sunnis. Here, then, Mujahids reveal and acknowledge the specificities of their movement and its roots within broader 2othcentury Kerala-wide projects of social reform and modernity. ${ }^{19}$

Concerns about Christian missionary propaganda, about the modernisation of religious education and its introduction into rapidly expanding state schools, about access to 'western' education, about

17 Although this goal is closest to the hearts of Mujahid reformists, it has also been picked up by mainstream organisations: the Muslim Students Federation (student wing of the Muslim League) focused its 2004 annual conference on 'Cordoba and Islamic Culture'; unity and forging global links is also subscribed to by Sunnis, who are equally enthusiastic and successful in drawing financial and ideological support from the Gulf.

18 The Madavoor faction opposed attempts to steer the Mujahid movement towards the normative strictures of Saudi salafism. This is one of the factors which generated the split within the KNM. We thank Shajahan Madampat for drawing our attention to these events.

${ }^{19}$ The driving force of the KNM's forerunner-Aikya Sangam—was Vakkom Abdul Khadir Moulavi (1873-1932), born into a wealthy Travancore Muslim business family. His relationship with the Izhava saint and reformer Sree Narayana Guru and his admiration for the Pulaya social reformer Ayyankali is well documented. Muslim reformists from all over Kerala converged around Wakkom Moulavi and continue to refer to him as a foundational inspiration (Jasmine 2002; Samad 1998; Miller 1976: $275^{\mathrm{ff}}$.). 
participation in government, about the need for public representation, were central for all the caste/religious movements which emerged across Kerala in the early part of the 2oth century. Smarting under colonial and missionary criticisms and noting the rapid economic development enjoyed by local Christians, all reform movements linked the goals of progress and modernisation to the embracing of 'western' forms of education, employment and business, as well as to the reforming of 'traditional' socio-religious practices which became branded as money-wasting superstitions. Socio-economic and religious reforms were assumed by 1920 s and 1930 os leaders to go hand in hand (Jeffrey 1976; Fuller 1976; Osella \& Osella 2000; Kodoth 2001; Devika 2002). In Kerala, communism, literacy, social reform and an outward orientation (characterised, for example, by a longstanding 'culture of migration') have all entwined to make a selfconscious 'Malayali modern' identity, putatively superior to Indians of other states. Reform, with its universalist and progressive flavour, is then both symptom of modernity and-like modernity—is necessarily worked out as a project which is simultaneously local and transnational (Osella \& Osella 2006).

\section{Socio-Religious Reforms in Kerala}

As in the rest of India, the role of members of educated elites in the development of reform movements and political organisations from the 1920 s onwards is not at all unusual. As among their Hindu counterparts, the message of socio-religious reform, modernization and 'progress' for the whole Muslim community found support especially amongst the educated middle classes. Indeed Mujahid leaders argue that the movement's success and influence comes down to their ability to join forces with the modernizing middle classes on a platform of socio-religious reforms. Kodungalloor, ${ }^{20}$ with a wealthy landowning and educated Muslim elite, became the cradle of reformism. Into the town converged not only religious reformers from central/southern Kerala area, but also a number of Muslim leaders who had been forced to flee Malabar after the 1921 Mappila lahala

${ }^{20}$ Cranganore, in central Kerala; erstwhile Cochin princely state and site of Kerala's first ever mosque. 
(uprising). ${ }^{21}$ It is here in 1922 that the Muslim Aikya Sangham was born, an ulema organisation campaigning to "unite all Muslims .... to educate...to reform religious, moral and economic conditions of Muslims by removing anti-Islamic practices" (Samad 1998: 81-82). During its short life (in 1934 it merged with the more politicised Kerala Muslim Majlis) the Sangham focused primarily on the development and reform of religious education, but it also endorsed a wider modernist agenda. ${ }^{22}$ In Kozhikode at that same period, we find Muslim merchants and traders, Koyas in particular, doing relatively well under British rule and many 'community leaders'wealthy and substantially Anglophile in orientation-enthusiastically embracing colonial-driven modernisation. Koya merchants built two 'modern' schools in Kozhikode (Himayatul Islam High School, in 1908, and Madrasathul Muhammadiya Vocational High School, 1918) with the blessings of the colonial administration and support from the Sangham. Active in Kozhikode's public administration, they also promoted the introduction of modern health and sanitation in the city's Muslim neighbourhoods donating land and money for the construction of local dispensaries and clinics.

But the conditions for the development of reform movements amongst Muslims are significantly different from other communities. Muslim reformism had to deal with the heavy issue of the aftermath of the 1921 Mappila lahala from which urban middle classes, after initially putting their weight behind the Khilafat movement, eventually distanced themselves. ${ }^{23}$ Amongst rural Muslims, in the heartland of Mappilas' many uprisings, the benefits of the colonial

${ }^{21}$ See e.g. Dale 1980; Panikkar 1989 for different analyses, stressing the lahala as anti-colonial/anti-landlords uprising or as Muslim jihad.

${ }^{22}$ The Sangham's 2nd conference (1923) was presided over by Abdul Jaffar Hazrat, principal of Baqiyattu-Salihat Arabic College of Vellore, who encouraged participants to promote English education amongst Muslims. At the $4^{\text {th }}$ conference, in 1926, Muhammad Marmaduke Pickthall—British novelist and journalist who, after converting to Islam, translated the Quran in English-argued that science was not a prerogative of Christians, asked for the introduction of a youth voluntary structure along the model of the Boy Scouts and called for the development of modern farming methods amongst Muslims. In 1928 the Sangham started a-short lived-Muslim bank and in 1933 an agricultural exhibition to showcase Muslims' use of new scientific techniques of cultivation was held alongside the last annual conference (Samad 1998: 8off.).

${ }^{23}$ While the visit of Gandhi and other leaders of the Khilafat movement attracted large crowds, Kozhikode remained substantially peaceful during the whole period of the lahala. To be sure, the presence of British gunboats offshore Kozhikode played a part (Dale 1980: 199). 
modernity embraced by Kozhikode's urban trading middle classes were far from clear. Three hundred years of colonial penetration and resulting impoverishment of agricultural tenants and labourers were understood as the expression of a wider Euro-Christian attack against

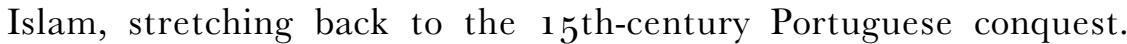
The bloody repression of the uprisings did nothing but confirm that the British were out to rid Malabar of Muslims and Islam. ${ }^{24}$ For the 'traditionalist' ulema-in whose practices and orientations the majority of rural Muslims recognised themselves-opposition to Islamic reformism coalesced with a generalised rejection of the wider project of modernization promoted by reformists. ${ }^{25}$ In other words, outside the minoritarian and limited spheres of the educated urban middle classes and the reformist ulema, attempts to introduce 'modern' practices-such as English or scientific education-were seen with suspicion, if not altogether opposed.

Eventually, the chasm between urban 'modernism/reformism' and rural 'traditionalism/conservatism' was bridged in the postindependence period by bringing into the leadership of the Muslim League members of Hadrami Sayyid families—-such as Syed Abdurrahiman Bafaki Thangal and Panakkad Syed Mohammedali Shihab Thangal—who were highly respected and revered by rural and non-middle-class Muslims and by the dominant Sunni non-reformist ulema. The Muslim League, emerging as the sole representative of the community's interests, managed to bring some rapprochement between Mujahid reformism and Sunni 'traditionalism' in the name of political unity-identified as a paramount necessity in dealing with the predicaments of post-partition democratic politics—while also helping push Sunni leaders towards an agenda of moderate reform for the

24 The British administration contemplated the deportation to the Andaman \& Nicobar islands of all Muslims in the areas affected by the 1921 lahala. Although this policy was abandoned for logistical reasons, eventually several thousands of Mappilas were deported (Miller 1992: 149).

${ }^{25}$ We are not suggesting here that early reformist leaders supported colonial rule. Indeed many of them—such as Muhammed Abdul Rahiman Saheb, Moidu Moulavi, K. M. Moulavi and E. K. Moulavi-spearheaded the independence movement in Malabar. In non-reformist rhetoric, however, such leaders became branded as 'antiMuslim' for their association to the Indian National Congress which was perceived to be Hindu-dominated, and to have betrayed the Khilafat movement and the lahala. By and large (but not exclusively), non-reformist ulema later aligned themselves with the Muslim League. 
sake of community 'development' and 'progress' ${ }^{26}$ From an all-India perspective, then, even Kerala's Sunni 'traditionalists' appear modern and reform minded to a degree (cf. Blank 2001).

\section{Reformism in Practice}

Back in Thekkepuram, our Koya friends and respondents, unlike the ulema, seldom talked to us about the cleavage between Sunni and Mujahids in doctrinal terms of shirk, bidah, taqlid or ijtihad. Commonly, differences were expressed by reference to orthopraxy, as distinct ways of praying-from the way hands are held, to the recitation of Qunooth during the Al-Fajir salat (dawn prayer), etc. in other words, through cultivation of a particular habitus and especially through daily embodied practice (cf. Mahmood 2004; Soares 2005: 187) ${ }^{27}$ Mujahid-oriented women spoke about reform meaning correct use of pardah dress (mafta and full coat or abaya) and avoidance of any un-Islamic practice-ranging through the celebration of birthdays or wearing nail varnish to calling on the martyr-saints. They also always stressed to Caroline their relative freedom compared to Sunni women: they are encouraged rather than prevented from pursuing education and attending mosque. But respondents were always also keen to point out that, in the end, "We are all Muslims", that Sunnis and Mujahids are substantially alike and that differences are not of kind, being akin to those "between Catholics and Protestants". Within families, sectarian differences are discussed with teasing and jokes. Fatima, a Mujahid madrasa teacher, interrogated Caroline about the details of her religious practice, concerned to check that Caroline did not indulge in 'saint worship'. Meanwhile Fatima's aunt-a devout Sunni-told Caroline, "If you ever convert, I know you will come over to us. You sing in church: well, if you join the Mujahids there is no singing, but we Sunni women have such beautiful songs".

26 The Muslim League's orientation has since been one of cautious reformism, where policies are dictated by pragmatism-the need to maintain unity and to participate in state government-rather than by possibly divisive ideological or religious considerations.

${ }^{27}$ Worried about this, one Mujahid scholar writes “...can anyone say that people run to us seeing our practice of putting hands on the chest [while praying], observing 11 Rakath Tharaveeh and avoiding Qunooth? We should remember how our ancestors attracted people to our religion" (A. A. S. Sullami 2002). 
Ulema debating issues of 'public interest' or the 'common good' (Ar. maslaha/maslaha amma) distinguish between disagreements which amount to contradiction and those which produce variety, and are to be welcomed (Zaman 2004: 148). A degree of disagreement within the community is then not necessarily seen as problematic. While Sunnis and Mujahids continue to frequent different mosques, there are little traces of the public confrontations and social boycotts which characterised past relationships between the two camps. Those who embraced-as young men-the Mujahid cause in the $195^{\circ}$ os and 1960 invariably recall severe beatings from their fathers and the open hostility of their neighbours, telling even of being pelted with rotten fruit and vegetables on returning from Mujahid meetings and mosques. The feeling that one has in contemporary Kozhikode is that cards have been dealt and divisions have fallen into the predictable routine of everyday life, where some families are recognised to be 'traditionally' aligned with Mujahids or Sunnis, while in others followers of either orientation coexist amicably. And intermarriages are commonplace. Nowadays, there are very few Kozhikode 'conversions' to reformism: young men or women are Mujahids because their families are Mujahids and they therefore have been socialised into reformism, for example, by receiving religious education in a Mujahid madrasa. 'Conversions', on the other hand, are numerous in the Gulf, where reformist organisations are extremely active-more so than are Sunnis-offering migrants support and drawing them into social functions and networks through which Muslim Malayali sociality is replicated and celebrated. Any changes in religious orientation taking place among Gulf migrants are less due to exposure to Saudi or Kuwaiti reformism—with which migrants have a highly limited and indirect exposure-than to intensified association with Malayali Mujahid groups.

The current lack of antagonism between Sunnis and Mujahids is only partly explained by this apparent routinisation of difference. In recent years a 'coordination committee' has been instigated by a number of Muslim entrepreneurs and industrialists - many of whom are running Gulf-based business empires (Osella \& Osella 2007c). Spurred by the 1990 os rise to government of Hindu nationalist parties, it brings together religious leaders of different groups to foster unity within the community. It has managed to resolve some of the most apparent expressions of religious factionalism, bringing consensus, for example, over the timings of the beginning of ramzan and the setting of eid. But what we want to note here is that Mujahid reformism does not appear 
to the 'unreformed' as controversial or threatening as it did 5 o years ago because much of what it insists upon has by now become taken for granted more widely, as the dominant and normative means through which to express and experience engagements with modernity and progress. Reformism, focusing on repudiation of 'backward' custom through religious learning and 'modern' education, holds far wider significance as a necessary aspect of the modern outlook of the Muslim middle classes and as normatised part of a distinctively 'progressive' Malayali identity.

In Kozhikode, traditionalism has become associated to ignorance, superstition and uncouthness; it is seen as characteristic of either rural (Mappila) or poor Muslims, to the extent that even 'orthodox' and unreformed Koyas no longer participate openly in urs such as Sheikh Palli nercha. Public religiosity and community-building are instead nowadays expressed in family-oriented rallies, 'social meets' and mass prayers. Communal eid prayers, for example, are organised in parks and on the beach by reformist groups; every year, these attract thousands of Kozhikode Muslims, men and women. While men and women pray in separate sections, this is a mixed and family occasion.

While some 'traditionalist' practices in Thekkepuram are increasingly confined to the domestic realm and while some traditionalist-leaning Koyas refuse indignantly the label 'Sunni' and try to define themselves simply as 'just Muslims', organisations devoted to the social and educational 'upliftment' of Muslims are thriving. Reformism in its social aspect has become the dominant framework, leading to the replacement of older forms of socialitywhen men gathered in local 'clubs' to play cards and consume alcohol—with new, such as involvement in NGOs or public functions. Groups such as Citizens' Intellectual Educational Social and Cultural Organisation (CIESCO) - formed in $195^{6}$ by a group of high school students-emerged within the general atmosphere of social activism which characterised post-independence Kerala, exemplified by the famous 'library movement' (Nair 1993). Organisations like CIESCO not only campaign for and support Muslim children's formal education (CIESCO runs a private English-medium school), but also organise regular camps or seminars to entertain, educate and inspire local Muslims. Today, Mujahid and Sunni supporters are equally involved in CIESCO's management committee; a women's wing-the wives of male committee members-organises separate functions for women. Local women enjoy these socio-cultural public programmes which combine entertainment (children's dance performances; cake baking 
competitions; henna hand-painting) with reformism: speeches on how to live a moral active and rationalised Muslim life delivered by community leaders, educationalists, public health workers or women felt to be useful community role-models. At a host of meetings run by organisations like CIESCO, Muslims are inducted into the idea that they should be aiming for a 'systematic life' (Mahmood 2004; Robinson 2004; cf. Watt 2005). Post-colonial modernity has then offered fertile grounds for the flourishing of a standardised, partly reformed and universalising Islam of convergence which is selfconsciously 'progressive'.

\section{Conclusions}

Nile Green (this volume) eloquently demonstrates that we cannot analyse shifts in Muslim society without situating such shifts within the wider social milieu. Kozhikode Koya enthusiasm for reform is clearly part of Kerala-wide patterns: 1920s and 1930s agitations to break

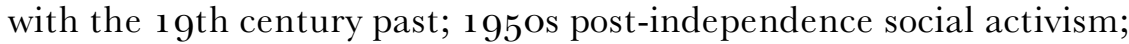
post 1980 os religious revivalism. It even focuses on many of the same core issues, such as education. We hear from Kerala's Mujahids a critique of Thangals-accorded respect by traditionalist Sunnis-as being an oppressive elite: fond of superstitions, perpetuating castelike differences, keeping learning as a monopoly and maintaining ignorance among others, while living off the back of people's devotion. These charges are similar to low caste and reformist Hindu critiques of Brahmans. Similarly, the Mujahid stress on monotheism necessarily reminds us of reformed Hindu discourses such as Advaita Vedanta, or the work of (e.g.) Sree Narayana Guru in Kerala who was reacting around the turn of the 2oth century to missionary accusations of 'idolatry' and 'devil worship'. Reform is of course attractive to certain sections of any population. As among Kerala Hindus and Christians (e.g. the reformed Marthoma Protestant church), we find among Kerala Muslims the association of religious reformism with a selfconsciously 'modern' outlook, through promotion of education and the rallying of support from the middle classes, with a concomitant association of orthoprax traditionalism to 'backward', superstitious and un-modern practices troped as being specific to in rural and lowstatus locations.

The major differences which mark the specificity of the Muslim experience of reform in Kerala are, firstly that rural Malappuram 
Muslims (Mappilas) were in a poorer, more downtrodden condition than rural low caste Hindu groups; secondly, that Muslims had a smaller middle class which could move to promote reform and agitate for change; thirdly, that early moves towards reformism among Muslims were slowed down by a wave of conservatism in Malabar, following the brutal crushing by the British of the Mappila lahala and general British anti-Muslim sentiments. But the entire social landscape has changed dramatically since the $195^{\mathrm{O}} \mathrm{s}$ and now even the 'traditionalists' are running engineering colleges. What we have tried to do here is to show how reformist rhetoric has pushedand continues to push-the entire Muslim community towards not broad 'reform' but specifically to crafting a vision of and programmes for a modern Muslim moral community. Reformism, via the central tropes of enlightenment, education, rationality and so on, has become imbricated with more generalised ideas about progress. A 'modern' and 'systematic' life with good secular education for one's children is now a widespread aspiration.

We have insisted that Kerala Islam is deeply local. This is not, pace Imtiaz Ahmad, because it is rooted in syncretic or sufi-inspired practice; as we have seen, it is extremely hostile to such practice. But neither should such practice anyway be read as necessarily the trope for what sort of Islam is authentically 'South Asian'. Nercha/urs, rateeb and so on are themselves not 'South Asian', but are aspects of Islam: those working in West Africa, South East Asia-even in parts of the Arab world-will recognise similar practices as part of popular Islam (Manger 1998). Caroline's embroidery class colleagues were offended by her questions about what a nercha and a Hindu utsavam have in common: it is clear that, even if blessed oil is offered to devotees at a shrine, for the Muslim participants this is quite different in meaning and sacred-emotional structure from a Hindu festival, and we must take seriously our respondents' insistence that this is so (cf. Werbner 2003). We must not ride rough-shod, but must recognise as critical such distinctions in how people live their faith.

We have also traced some processes of production of categories of 'reformism' and 'traditionalism'. While reformists are split between several tendencies and debates continue about what are reform's core aspects, reformists unite around a general concern with shirk, still now sometimes leading them into confrontation with Sunnis. In Kerala's fully literate state, the proliferation of newspapers aligned to particular sections underwrite these processes: Kerala has five Muslim newspapers. Adoption of stricter practices—such as take-up 
of full veiling-comes partly in response to all-India politics, partly as assertion of middle class and 'modern' status and only partly as response to Gulf exposure (Osella \& Osella 2007b). Mujahid and Sunni alike invite Arab ulema to make speeches at functions and both groups successfully raise cash for projects from Arab benefactors. And the fact is that shrine festivals and mosque building alike proliferate with Gulf money, a tendency we situate as part of a Kerala wide, all-community, religious revivalism (Tarabout 1986; Osella \& Osella 2003; cf. Gardner 1985; Ewing 1997).

Our 'localist' analysis does not in turn imply that Kerala's Mujahid movement is not part of a wider tendency within Islam towards reform (Robinson this volume). We must acknowledge reformist aspirations to universalism: how often in Kozhikode will somebody confidently inform us, "Islam says this" or, "Muslims must do this", speaking for all. Joel Kahn argues against the branding of radical Islam as "particularistic, backward looking and fundamentalist" and insists that it is instead "just as universalist ... as are western movements for human rights ..." (Kahn n.d.: 5). Kerala's Mujahid movement, while certainly neither identical nor mere imitation, is obviously inspired by similar core ideals and shares some founding influences (e.g. Mohammad ibn Abdul Wah'hab, Muhammud Abduh) with reformist movements right across the Muslim world. Noting this, and observing the continual troping of Mujahid v/s Sunni as modern v/s backward, leads us towards arguments suggesting that what Robinson has identified as the drive to perfection may be a feature not specifically of Islam, but a feature available within Islam (as in some other religious traditions) and especially likely to flourish under conditions of modernity (Kahn n.d.; cf. Robinson 2004). We need then to trace out the modern roots of reform, which are contributing to its contemporary success in many locations, while simultaneously taking on board reform Islam's claim-as Mujahid leaders reiterate to us-not to be anything created from new but to be a strand of time-honoured practice.

Finally, we note with interest the emergence around Kozhikode of an identity as 'just a Muslim'-neither one nor the other. A few of our respondents insisted upon the fact that they were not aligned with either Mujahids or Sunnis nor even more broadly with 'reform' or 'orthodoxy'. Such people might be, for example, open to ideas about western education and use of the vernacular for khutba, but unwilling to insist upon strict reformist-style pardah for their womenfolk; they may argue against Thangals holding high status and political office 
but argue that it is not necessary to abandon attendance at shrines. Ideological debates between Mujahids and Sunnis, their leaders' high public profile, the existence of media sponsored by and aligned with particular groups have all over-determined public discourse, such that it seems almost impossible to avoid taking a clear public stance on one's affiliation for one or the other group. But in private practice many people are negotiating doctrinal issues in relation to complex and contradictory demands of everyday life, where families strive to provide best opportunities for their children in an increasingly highly competitive and globalized labour market. While ijtihad may be imagined by leaders as the privilege of the ulema, it does appear that reform paves the way for further democratisation of and critical engagement with religious practice (cf. Robinson 2004). Ben Soares tracks in Mali, as we have tracked for Kozhikode, the ways in which a reformist minority have been able to influence and shift majority practice and thinking (2005: 206). At the same time, he argues that the development of the postcolonial public sphere has also encouraged a general standardising of Islam, a convergence between reformists and their opponents as Islam comes to be defined around core universalistic values such as the haj or observance of Ramzan (2005: 187, 200ff). While it seems highly unlikely that in Kerala any charismatic leader ${ }^{28}$ as in the Malian case would emerge, those who refuse to be labelled Sunni or Mujahid but lay claim to be 'just a Muslim' may perhaps also come in time to articulate a formal position which would transcend the present binary and be attractive to others. But, as Simpson has shown us, all such developments are over-determined by political events (this volume). Because Kerala Muslims are forced continually to react, within the state, the nation and the world at large, it is impossible to predict what directions Islam here may take in future.

\section{Bibliography}

Abaza, M. 2002. Debates on Islam and Knowledge in Malaysia and Egypt: Shifting Worlds. Curzon Routledge, London.

Abdel Rahman, M. 20o6. 'Divine Consumption: Islam and Consumerism in Egypt'. In Abdel Rahman et al. (eds.). Cultural Dynamics in Contemporary Egypt, Cairo Papers $27,1 \& 2$.

Abdul Haque, P. P. 1982. 'Islahi Movement in Kerala'. Almuneer, February: 61-67.

${ }^{28} \mathrm{He}$ is a flamboyant media star who has a project of "shaping of moral subjects in the public sphere ... that also includes a social agenda advocating fund raising for education and the poor" (Soares 2005: 253). 
Ahmad, I. \& H. Reilfeld (eds.). 2004. Lived Islam in South Asia: Adaption, Accommodation and Conflict. Oxford University Press, Delhi.

Asad, T. 1986. The Idea of an Anthropology of Islam. Georgetown University Center for Contemporary Arab Studies, Washington, DC.

Bayly, S. 1992. Saints, Goddesses and Kings: Muslims and Christians in South Indian Society I700- I900. Cambridge University Prexss, Cambridge.

Blank, J. 2001. Mullahs on the Mainframe: Islam and Modernity Among the Daudi Bohras. Chicago University Press, Chicago.

Bowen, J. R. 1993. Muslims Through Discourse: Religion and Ritual in Gayo Society. Princeton University Press, Princeton, NJ.

Brenner, S. 1996. "Reconstructing Self and Society: Javanese Muslim Women and 'the Veil'" American Ethnologist, 23(4): 673-697.

Dale, S. F. 1980. The Mappilas of Malabar, 1498-192 2: Islamic Society on the South Asian Frontier. Clarendon, Oxford.

Dale, S. F. 1997. 'The Hadrami Diaspora in South-Western India: The Role of the Sayyids of the Malabar Coast. In Freitag, U. \& W. Clarence-Smith (eds.). Hadhrami Traders, Scholars and Statesmen in the Indian Ocean, I 75 os-196os. Brill, Leiden.

Deeb, L. 2006. An Enchanted Modern: Gender and Public Piety in Shi'I Lebanon. Princeton University Press, Princeton, NJ.

Devika, J. 2002. Domesticating Malayalees: Family Planning, the Nation and Home-Centred Anxieties in Mid-2 oth Century Keralam. Centre for Development Studies, Trivandrum, Kerala, India. Working Paper 340.

Eickelman, D. F. \& J. Piscatori. 1996. Muslim Politics. Princeton University Press, Princeton, NJ.

Eickelman D. F. \& A. Salvatore (eds.). 2004. Public Islam and the Common Good. Brill, Leiden.

Ernadan, K. V. K. 1979. Kuttichira Sunni Mujahid Vaada Pradivaada Samgraham. Irshadiyya Publications, Pulikkal, Kerala.

Ewing, K. 1997. Arguing Sainthood: Modernity, Psychoanalysis and Islam. Duke University Press, Durham, NC.

Fanselow, F. 1996. 'The Disinvention of Caste Among Tamil Muslims'. In Fuller, C. (ed.). Caste Today, pp. 202-226. Oxford University Press, Delhi.

Freitag, U. \& W. Clarence-Smith (eds.). 1997. Hadhrami Traders, Scholars and Statesmen in the Indian Ocean, I750s-1960s. Brill, Leiden.

Freitag, U. 2003. Indian Ocean Migrants and State Formation in Hadhramaut. Brill, Leiden.

Fuller, C. J. 1976. The Nayars Today. Cambridge University Press, Cambridge.

Gardner, K. 1985. 'Mullahs, Migrants and Miracles: Travel and Transformation in Rural Bangladesh'. Contributions to Indian Sociology (ns). 27, 2: $213-235$.

Gellner, E. 1981. Muslim Society. Cambridge University Press, Cambridge.

Green, N. 2005. 'Mystical Missionaries in the Hyderabad State: Mu'in Allah Shah and his Sufi Reform Movement'. The Indian Economic and Social History Review. 42, 2: 187-212.

Gupta, C. 2002. Sexuality, Obscenity, Community: Women, Muslims, and the Hindu Public in Colonial India. Permanent Black, Delhi.

Haddad, M. 2006. 'The Manarists and Modernism'. In Dudoignon S. A., K. Hisao and K. Yasushi (eds.) Intellectuals in the Modern Islamic World: Transmission, Transformation and Communication. pp. 55-73. Routledge, London.

Hermansen, M. 2000. 'Fakirs, Wahhabis and Others: Reciprocal Classifications and the Transformation of Intellectual Categories'. In Malik, J. (ed.). Perspectives of Mutual Encounters in South Asian History, I760-I86o, pp. 23-48. Brill, Leiden.

Hirschkind, C. 2001. 'Civic Virtue and Religious Reason: An Islamic Counterpublic'. Cultural Anthropology. 16, 1: 3-34. 
Hirschkind, C. 2006. The Ethical Soundscape: Cassette Sermons and Islamic Counterpublics. Columbia University Press, New York, NY.

Ho, E. 20o6. The Graves of Tarim: Genealogy and Mobility across the Indian Ocean. University of California Press, Berkeley, CA.

Jasmine, A. 2002. Social and Cultural Milieu of Muslims of South Kerala, I850-1950: Contributions of Vakkam Maulavi. Unpublished PhD Thesis, University of Kerala, Trivandrum, Kerala.

Jeffery, P., R. Jeffery \& C. Jeffrey. 2004. "Islamization, Gentrification and Domestication: a Girls' 'Islamic Course' and Rural Muslims in Western Uttar Pradesh'. Modern Asian Studies. 38, 1: 1-53.

Jeffrey, R. (1976) 1994. The Decline of Nayar Dominance. Manohar: Delhi.

Jones, C. 2007. "Fabric and Fetish: Debates on Busana Muslim in Contemporary Urban Indonesia." Journal Fashion Theory, vol 11 , issue 2/3.

Joshi, S. 2001. Fractured Modernity: Making of a Middle Class in Colonial North India. Oxford University Press, Delhi.

Kahn, J. n.d. Clash of Universalisms: Reflections on Modernity, Asia and Exclusion, Lecture delivered at Asian Culture Symposium, Gwangju, Korea, February 2005.

Kodoth, P. 2001. 'Sexuality, Sambandham and Marriage Reform in Late Nineteenth Century Malabar'. Modern Asian Studies. 35, 2: 349-384.

Laffan, M. 2002. Islamic Nationhood and Colonial Indonesia: The Umma Below the Winds. RoutledgeCurzon, London.

Mahmood, S. 2004. Politics of Piety: The Islamic Revival and the Feminist Subject. Princeton University Press, Princeton, NJ.

Manger, L. 1998. Local Islam in Global Contexts. Curzon, London.

Mayaram, S. 1997. Resisting Regimes: Myth, Memory and the Shaping of a Muslim Identity. Oxford University Press, Delhi.

McGilvray, D. 1989. 'Households in Akkaraipattu: Dowry and Domestic Organization Among Matrilineal Tamils and Moors in Sri Lanka”. In Gray, J. N.et al. (eds.) Society From the Inside Out: Anthropological Perspectives on the South Asian Household, pp. 192-235. Sage, New Delhi.

McGilvray, D. 1998. "Arabs, Moors and Muslims: Sri Lankan Muslim Ethnicity in Regional Perspective". Contributions to Indian Sociology (ns). 32, 2: 433483 .

McGilvray, D. 2004. 'Jailani: A Sufi Shrine in Sri Lanka'. In Ahmad, I. \& H. Reifeld (eds.). Lived Islam in South Asia: Adaptations, Accommodations and Conflict, pp. 273-289. Social Science Press, Delhi.

Metcalf, B. 1982. Islamic Revival in British India. University of California Press, Berkeley, CA.

Metcalf, B. 1976. 'Review of Separatism Among Indian Muslims'. The Journal of Asian Studies. 35, 2: 339-341.

Metcalf, B. 2002. 1990. Perfecting Women: Maulana Ashraf'Ali Thanawi's Bihishti Zewar: A Partial Translation with Commentary. Oxford University Press, Delhi.

Miller, R. E. 1992. Mappila Muslims of Kerala: a Study in Islamic Trends. Orient Longman, Madras, India.

Minault, G. 1982. The Khilafat Movement: Religious Symbolism and Political Mobilization in India. Columbia University Press, New York, NY.

Minault, G. 1998. Secluded Scholars: Women's Education and Muslim Social Reform in Colonial India. Oxford University Press, Delhi.

Mines, M. 1973. 'Muslim Social Stratification in India: The Basis for Variation'. Southwestern Journal of Anthropology. 28: 333-349.

Mines, M. 1975. 'Islamisation and Muslim Ethnicity in South India'. Man (ns). 1o, 3: 404-419. 
Mobini-Kesheh, N. 1997. 'Islamic Modernism in Colonial Java: The Al-Irshad Movement'. In Freitag, U. \& W. Clarence-Smith (eds.). Hadhrami Traders, Scholars and Statesmen in the Indian Ocean, I $7505-1960 s$, pp. 231-248. Brill, Leiden.

Nair, R. 1993. 'Origins of People's Library Movement in Kerala'. Granthana. 4, 1 \& 2: $29-36$.

Osella, F. \& C. Osella. 20oo. Social Mobility in Kerala: Modernity and Identity in Conflict. Pluto, London.

Osella, F. \& Osella, C. 2003. "Migration and the Commoditisation of Ritual: Sacrifice, Spectacle and Contestations in Kerala, India". Contributions to Indian Sociology. 37, 1 \& 2: 109-140.

Osella, F. \& C. Osella. 20o6. 'Once Upon a Time in the West? Stories of Migration and Modernity From Kerala, South India'. Journal of the Royal Anthropological Institute. $12,3: 5^{69-588 .}$

Osella, F. \& C. Osella. 2007a. "I am Gulf”: The Production of Cosmopolitanism in Kozhikode, Kerala, India'. In Simpson, E. \& K. Kress (eds.). Cosmopolitanism Contested: The Confluence of History and Anthropology in the Indian Ocean. pp. ???? Hurst, London.

Osella, C. \& Osella, F. 20o7b. 'Muslim Style in south India'. Journal Fashion Theory. vol 11 , issue 2/3: 1-20.

Osella, F. \& C. Osella. 2007c. 'Muslim Entrepreneurs Between India and the Gulf', ISIM Review. 19, 8-10.

Panikkar, K. N. 1989. Against the Lord and the State: Religion and Peasant Uprisings in Malabar I 836-I92 I. Oxford University Press, Delhi.

Pasha, K. 1995. 'Muslim Religious Education'. In Asghar Ali Engineer (ed.). Kerala Muslims: A Historical Perspective, pp. 133-146. Ajanta, Delhi.

Rawther, M. K. 1993. Moidu Moulavi: A Political Bibliography. Unpublished M.Phil Thesis, University of Calicut, Kerala.

Robinson, F. 1993a. Separatism Among Indian Muslims: The Politics of the United Provinces Muslims I 860-1923. Oxford University Press, Delhi.

Robinson, F. 1993b. 'Introduction to the Paperback Edition'. In Separatism Among Indian Muslims: The Politics of the United Provinces Muslims I 86o-I923, pp. XIV-XXV. Oxford University Press, Delhi.

Robinson, F. 2001 a. 'Islam and Muslim Society in South Asia'. In Robinson, F. Islam and Muslim History in South Asia, 44-65. Oxford University Press, Delhi.

Robinson, F. 2001b. The 'Ulama of Farangi Mahal and Islamic Culture in South Asia. Permanent Black, Delhi.

Robinson, F. 2004. 'Other-Worldly and This-Worldly Islam and the Islamic Revival'. Journal of the Royal Asiatic Society. 14, 1: 47-58.

Roy, O. 2004. Globalised Islam: The Search for a New Ummah. Hurst, London.

Salvatore, A. 1997. Islam and the Political Discourse of Modernity. Ithaca Press, Reading, MA.

Samad, M. A. 1998. Islam in Kerala: Groups and Movements in the 2oth Century. Laurel Publications, Kollam, Kerala.

Sanyal, U. 1996. Devotional Islam and Politics in British India: Ahmed Riza Khan and His Movement, I870-1920. Oxford University Press, Delhi.

Sathar, M. A. 1999. History of Ba-'Alawis in Kerala (2 volumes). Unpublished $\mathrm{PhD}$ Thesis, University of Calicut, Kerala.

Schomburg, S. E. 2003. "Reviving Religion": The Qadiri Sufi Order, Popular Devotion to Sufi Saint Muhyiuddin 'Abdul Qadir al-Gilani, and Processes of 'Islamization' in Tamil Nadu and Sri Lanka. Unpublished PhD Thesis, Harvard University.

Sikand, Y. 2002. The Origins and Development of the Tablighi-Jama'at (I920-20oo). Orient Longman, New Delhi. 
Sikand, Y. 2005. Bastions of the Believers: Madrasas and Islamic Education in India. Penguin, Delhi.

Sikand, Y. 2007. 'The Reformist Sufism of the TablighiJamaat: The Case of the Meos of Mewat'. In Hasan, M. (ed.). Living with Secularism: The Destiny of India's Muslims, pp. 37-62. Manohar, Delhi.

Simpson, E. 2006. Muslim Society and the Western Indian Ocean: The Seafarers of Kachchh. Routledge, London.

Soares, B. 2005. Islam and the Prayer Economy: History and Authority in a Malian Town. Edinburgh University Press, Edinburgh, UK.

Srinivas, M. N. 1966. Social Change in Modern India. Allied Publishers, Bombay, India.

Srinivas, S. V. 1996. 'Devotion and Defiance in Fan Activity'. Journal of Arts and Ideas. January: $67-83$.

Sullami, A. A. S. 2002. 'Propagation in a Society with Multi-Religion: Its Style and Features' (translated from Malayalam). In Souvenir of the Mujahid State Conference 2002, Calicut, Kerala.

Tarabout, G. 1986. Sacrifier et Donner a Voir en Pays Malabar. Ecole Francaise d'ExtremeOrient, Paris.

Troll, C. W. 1978. Sayyid Ahmad Khan: A Reinterpretation of Muslim Theology. Vikas, New Delhi.

Vatuk, S. 1996. "Identity and Difference or Equality and Inequality in South Asian Muslim society". In Fuller, C. (ed.). Caste Today, pp. 227-262. Oxford University Press, Delhi.

Verkaaik, O. 2001. 'The Captive State: Corruption, Intelligence Agencies, and Ethnicity in Pakistan. In Hansen, T. B. et al. (eds.). States of Imagination, pp. 345-364. Duke University Press, Durham, NC.

Verkaaik, O. 2004. Migrants and Militants : Fun and Urban Violence in Pakistan. Princeton University Press, Princeton, NJ.

Walsh,J. E. 2004. Domesticity in Colonial India: What Women Learned When Men Gave Them Advice. Oxford University Press, Delhi.

Watt, C. A. 2005. Serving the Nation: Cultures of Service, Association and Citizenship in Colonial India. Oxford University Press, Delhi.

Werbner, P. 2003. Pilgrims of Love: The Anthropology of a Global Sufi Cult. Indiana University Press, Bloomington, IN.

Zaman, M. Q. 1999. 'Religious Education and the Rhetoric of Reform: The Madrasa in British India and Pakistan'. Comparative Studies in Society and History. 41, 2: 294-323.

Zaman, M. Q. 2004. 'The 'Ulama of Contemporary Islam and their Conceptions of the Common Good'. In Salvatore, A. \& D. F. Eickelman (eds.). Public Islam and the Common Good, pp. 129-156. Brill, Leiden. 